\title{
NASILNO POKRŠTAVANJE SRBA U NEZAVISNOJ DRŽAVI HRVATSKOJ
}

\author{
Radoslav Gaćinović* \\ Institut za političke studije, Beograd
}

Tokom Drugog svetskog rata na teritoriji NDH ustaše su počinile najveće zločine protiv čovečnosti. Bile su to masovne likvidacije Srba, proterivanje i zlostavljanje u koncentracionim logorima. Srbi koji nisu proterani bili su izloženi masovnom prevođenju u katoličku veru. Glavnu ulogu u toj vrsti nasilja imala je Hrvatska katolička crkva i predstavnici NDH uz podršku Vatikana. U radu je detaljno analizirana uloga Alojzija Stepinca u nasilnom pokrštavanju Srba na teritoriji NDH, gde je u katoličku veru nasilno prevedeno više od 240.000 Srba.

Ključne reči: Vatikan, pokrštavanje, Srbi, nasilje, ustaše, Katolička crkva

\section{Uvod}

Ministar pravosuđa u Nezavisnoj Državi Hrvatskoj dr Mirko Puk izdao je, 18. jula 1941. godine, naredbu kojom je zabranio naziv „srpsko-pravoslavna vera” pošto nije u skladu sa državnim uređenjem, a umesto toga uveden je naziv „grčko-istočna vera”, pravoslavne verske škole su ukinute, a sveštenstvo proterano, dok su oni koji su bili uporni i nisu želeli da odu odvođeni u logore ili odmah ubijani. Vođstvo tzv. NDH od prvih dana širilo je netrpeljivost i pozivalo na uništenje Srba i na prostoru Bosanske krajine i Kozare. Tako je, na primer, advokat Viktor Gutić, jedan od najozloglašenijih predstavnika NDH u Bosanskoj krajini, i ustaški stožernik govorio: „Ove srpske Cigane poslaćemo u Srbiju, jedne željeznicom, a druge Savom bez lađa. Nepoželjni elementi biće iskorijenjeni tako da će im se zatrti svaki trag i jedino što će ostati biće sjećanje na njih. Svu srpsku gamad od petnaest godina pa naviše mi ćemo poubijati a nijhovu djecu smjestiti u klostere i od njih će biti dobri Hrvati". ${ }^{1}$ Da bi se sve ove vrste nasilja „ozakonile" izdavale su se razne naredbe. Tim poslovima rukovodilo je zloglasno ustaško Državno ravnateljstvo za ponovu u Zagrebu, koje je uspostavilo svoj specijalni verski odsek sa katoličkim sveštenikom na čelu. Prekrštavanje Srba odobreno je pismom od 17. jula 1941. godine, koje je upućeno iz Vatikana Alojziju Stepincu, u kojem je rečeno: „Ako Vaša preuzvišenost predoči tu potrebu svojoj časnoj braći (biskupima) u Hrvatskoj, steći će ponovnu zaslugu tim svojim dragocjenim doprinosom za pravilan razvoj katolicizma, gdje postoje tolike nade za

\footnotetext{
* Prof. dr Radoslav Gaćinović je naučni savetnik.

${ }^{1}$ Radoslav Gaćinović, Nasilje nad Srbima u XX veku (uzroci i posledice), knjiga druga, EVRO BOOK, Beograd, 2017, str. 180.
} 
obraćanje ne sjedinjenih " Time Stepinac dobija novu snagu za nastavak posla na pokrštavanju pravoslavnog stanovništva. U tom smislu saziva konferenciju biskupa na kojoj je izabran odbor od tri člana za rukovođenje ovim poslovima. Odbor su činili sam Stepinac, zatim senjski biskup Viktor Burić i križevački biskup Janko Šimrak. Izabran je i izvršni odbor sastavljen od još pet sveštenika. Dok su ustaše vršile masovne zločine nad srpskim stanovništvom, katolički kler je prekrštavao Srbe na teritoriji tzv. $\mathrm{NDH}^{2}{ }^{2} \mathrm{U}$ pojedinim biskupijama sami biskupi su bili inicijatori i odgovorni za prekrštavanje. Naređivali su pojedinim sveštenicima da odlaze kao „misionari” u pravoslavna sela i prekrštavaju stanovništvo. Oni koji su to odbijali bili su primorani raznim dekretima. Ovakve naredbe odnosile su se, pre svega, na mlađe sveštenike čija je obaveza bila da idu u srpska sela i obučavaju srpsko stanovništvo za prelazak na katoličku veru. Na teritoriji Kostajnice na poslovima prekrštavanja radio je Dionizije Juričević, lični kapelan ustaškog poglavnika Pavelića, koji je na terenu pokazao svoju sposobnost ubeđivanja. U mestu Stezi, pre prekrštavanja, govorio je okupljenom narodu: „U ovoj zemlji ne može više da živi nitko osim Hrvata, jer ovo je zemlja Hrvatska i tko se neće prekrstiti mi znademo kuda ćemo s njim. Ja sam u ovim gore krajevima davao očistiti od pileta sve do starca, a ako bude potrebe, učinit ću i ovdje, jer danas nije grehota ubiti ni malo djete od sedam godina, a koje smeta našem ustaškom poretku..." Prekrštavanje pravoslavnog stanovništva na teritoriji NDH, a posebno u Bosni i Hercegovini, pretvorilo se u organizovani sistem rada klero-ustaških vlasti na uništenju Srba. To dokazuje i pismo šezdesetorice Muslimana iz Banja Luke, uglednih građana odanih NDH i poglavniku Anti Paveliću, upućeno dr Džaferu Kulenoviću, potpredsedniku ustaške vlade u Zagrebu, i Hamdiji Bešlagiću, ministru prometa i javnih radova, koji jasno govore o zverstvima i nepravdama koja su počinjena nad Srbima u Bosanskoj krajini. U pismu se isticalo: „Ubijanje svećenika i prvaka bez suda i presuda, strijeljanje i žrtvovanje u gomilama posve nevinih ljudi, žena i djece, gonjenje u masama iz kuće $i$ iz postelje čitavih porodica sa rokom od jednog do dva časa za spremanje, te njihovo deportiranje u nepoznate krajeve, prisvajanje i pljačkanje njihove imovine, te siljenje u katoličku vjeru, sve su to činjenice koje su zaprepastile svakog istinskog čovjeka i koje su i na nas Muslimane ovih krajeva djelovale najneugodnije... Jedan dio katoličkog svećenstva smatra da je došao njegov čas i on ga bez skrupula iskorišćava. Propaganda za katolicizam je uzela toliko maha da podsjeća na špansku inkviziciju. Pod njezinim pritiskom i uz toleriranje javnih organa izvršeno je pokatoličavanje hrišćana u masama." ${ }^{3}$

Osim ovog pisma građana Banja Luke o teroru koji se sprovodi nad srpskim stanovništvom sa ovog područja postoji telegram koji je uputio italijanski vicekonzul u Banja Luci Oberto Fabiani, 9. jula 1941. godine, Kraljevskom poslanstvu u Zagrebu koji detaljno opisuje mere koje hrvatske vlasti sprovode nad Srbima sa područja bivše Vrbaske banovine. On daje detaljan opis svih mera koje su preduzete protiv pravoslavaca, kao i namere da se oni proteraju sa njihovih poseda, a imovina zapleni. Prema rečima vicekonzula, mnogi pravoslavci su tražili zaštitu od italijanske vlade koja se nalazila na ovoj teritoriji. Nekoliko dana kasnije, tačnije 26. juna, Oberto Fabiani šalje izveštaj Italijanskom poslanstvu u Zagrebu o proterivanju Srba i Jevreja sa teritorije bivše Vrbaske banovine: „Kako sam izvjestio gore označenim brzojavkama, premješteno je 13. t.mj. oko sto pedeset pravoslavnih obitelji... Odla-

\footnotetext{
${ }^{2}$ Prof. dr Aleksandar Rastović, Sedamdesetogodišnjica bitke na Kozari, Zbornik radova „Kozara spomenik našeg pamćenja”, Organizacioni odbor za obeležavanje sedamdesetogodišnjice bitke na Kozari, Beograd, 2012, str. 22-23.

${ }^{3} \mathrm{U}$ samom gradu Banja Luci bilo je prekršteno oko sto pedeset Srba, a na teritoriji njenog sreza do 21. oktobra 1941. godine prekrštena je 21.000 pravoslavnih stanovnika, str. 24.
} 
Iskustva i pouke iz prošlosti

skom gore navedenih obitelji koje su bile najbogatije u Banja Luci, broj se pravoslavaca ovdje smanjio za 2.000... Što se tiče nepokretnosti i općenito cijelog imetka, koji su ostavili u ovom gradu izbjeglice ili izgnanici ona je zaplijenjena od ovdašnjih vlasti... Što se tiče trgovina koje su pripadale pravoslavcima ili Židovima, a nalaze se u ovom gradu, one su velikim dijelom povjerene vodstvu hrv. povjerenika, koji su zatim postavljeni."4 Svoj odlučan glas protiv ubijanja i uništenja Srba u Hrvatskoj i Bosanskoj krajini podigao je vatreni katolik Prvoslav Grizonogo, koji je tokom 1941. i 1942. uputio nekoliko pisama beogradskom nadbiskupu Ujčiću i zagrebačkom nadbiskupu Stepincu u kojima je tražio prestanak progona Srba.

\section{Masovno pokatoličavanje Srba na teritoriji NDH}

Pokatoličavanje, odnosno pohrvaćivanje Srba, bio je zajednički cilj episkopata i ustaške vlade. „Nasilno pokatoličavanje srpskih masa, ubijanje i mučenje pravoslavnih sveštenika i vladika, rušenje njihovih crkava i manastira, koje se vrši u Hrvatskoj, tobože u interesu katolicizma, zadire bez sumnje i u interese vrhovnog vodstva katoličke crkve. Srbi su očekivali, da će Sveta Stolica kao čuvar ugleda katoličke crkve podići svoj glas pre ili kasnije i javno osuditi krvave progone, koji se vrše u ime katolicizma nad pravoslavnim kršćanima... Srbi se pitaju iz kojih razloga Sveta Stolica sada šuti na strašnu tragediju srpske pravoslavne crkve. Jedina odluka Svete Stolice, za koju su Srbi doznali i koja se tiče njih, je odluka 'Sv. Kongregacije za Istočnu Crkvu' od 17. jula 1941., potpisana od kardinala Eugena Tiseranta (Eugen Tisseraut). Odluka govori o prelazima pravoslavnih u katoličku veroispovest, te preporučuje hrvatskim biskupima, da ne prave pravoslavnima smetnje, ako se reše pri prelazu za istočni obred umesto latinskog, jer da će to koristiti pravilnom razvitku katolicizma u Hrvatskoj, gde postoje tolike nade u prisajedinjenje neprisajedinjenih." ${ }^{5}$ Poslednji stav u tekstu odluke Kongregacije morao je ispuniti Srbe dubokim nepoverenjem i učvrstiti ih u uverenju da u svojoj nesreći ne mogu računati ni na pomoć Hrvatske katoličke crkve, kao ni na zaštitu Svete Stolice... U Zagrebu je Vatikan imao svog legata (Marconea), koji je često putovao u Rim, te je tamo podnosio izveštaje. Međutim, na osnovu navedenih činjenica može se zaključiti da je, kao i prethodni hrvatski biskupi, u Vatikanu zastupao ustašku tezu i ustaške interese. Ni nakon toga Vatikan nije ništa preduzeo da bi se stvari izmenile nabolje, nego je, naprotiv, svim svojim delima pokazao da mu je stalo samo do zadovoljenja ustaštva i do ustaškog promovisanja katolicizma na hrvatskom delu Balkana. U tom smislu Vatikan je dao i neke druge, mnogo preciznije direktive od onih iz odluke Kongregacije za Istočnu crkvu U izveštajima ustaških „opunomoćenika” u Vatikanu Nikole Rušinovića i Ervina Lobkovića (Erwin Lobkowicz) ministarstvu vanjskih poslova u Zagrebu, ima mnogo momenata koji osvetljavaju pravu poziciju Vatikana u odnosu na prekrštavanje koje su sprovodile ustaše uz pomoć Hrvatske katoličke crkve.

\footnotetext{
${ }^{4}$ Radoslav Gaćinović, Nasilje nad Srbima u XX veku (uzroci i posledice), knjiga druga, EVRO BOOK, Beograd, 2017, str. 182.

${ }^{5}$ TAJNI DOKUMENTI o odnosima Vatikana i ustaške NDH, Biblioteka novinara Hrvatske, Štamparski zavod „Ognjen Prica”, Zagreb, 1952, str. 98.

${ }^{6}$ Isto, str. 99-100.
} 
Nikola Rušinović piše, 26. februara 1942. godine, Mladenu Lorkoviću o svojoj poseti kardinalu Maglioneu (Luigi Maglione), vatikanskom državnom sekretaru. Razgovor se vodio o jednoj vesti koja je izašla u turskom listu „La Republique” o masakru Srba u Hrvatskoj i o jednom navodnom protestu srpskog pravoslavnog patrijarha upućenog Vatikanu. Maglione je negirao da je takav protest stigao u Vatikan, a Rušinović je tvrdio da pokolja Srba nije bilo. Verovatno je kardinal Maglione shvatio da ustaša laže i izvrće činjenice, ali mu je ova "interpretacija” odgovarala, pa je bio veoma zadovoljan. Nikola Rušinović piše: „On je moja izlaganja pozorno slušao i izrazio zadovoljstvo nad tim, jer da još nije imao prilike da tako što čuje, nego samo neprijateljsku promičbu." Maglione je, dakle, bio prethodno dobro informisan o ustaškim zločinima, ali je te informacije nazvao „neprijateljskom promičbom”. Rušinović dalje piše: „Zatim smo došli na pitanje obraćenika, za koje tvrdi strana promičba da su pod teškim pritiskom vlasti napuštali svoju vjeru i prelazili na katoličku, da spase gole živote. Čini se, da ga je od svega to najviše zanimalo. Ja sam odmah naglasio, da se ne radi tu o obraćenicima, nego o povratnicima, jer do dolaska Turaka nije bilo u Hrvatskoj pravoslavaca. A kakvi su bili pritisci na hrvatski elemenat govore o tom povijesni dokumenti i pokazuju da su Turci omogućili infiltraciju Srba u Hrvatsku, a jedni i drugi nisu birali sredstva da bi ih (Hrvate) odvukli od njihove vjere i time oslabili nacionalnu snagu Hrvata. Spomenuh mu nadalje, da je zadnjih 20 godina otpalo od katoličke crkve 250.000 duša. Što se tiče povratnika naglasio sam, da je Hrvatska vlada to prepustila crkvi, i crkva je bila potpuno slobodna u tome, što mi je i sam Preuzvišeni Stepinac potvrdio pred moj odlazak u Rim, izjavivši da ih je mogao prevesti do 400.000 a nije nego tek 100.000, jer ih nije htio primati bez temeljite prijave, pošto je pravoslavni elemenat tako zaostao, da ne zna ni za najbitnija načela svete Vjere."

Istorijski falsifikat o tome kako su Turci doveli u Hrvatsku Srbe i kako su Turci i Srbi zajedno prisiljavali Hrvate da postanu pravoslavci, zatim da je u doba Jugoslavije prekršteno silom 250.000 Hrvata itd., za Maglionea su bile samo „lijepe izjave”, za koje je on bio „vrlo zahvalan". Ne može biti validnijeg dokaza od toga da je prvi papin zamenik, prema tome i sam papa, odobravao ovu akciju, da se Vatikan saglasio sa masovnim prekrštavanjem, da to nije bila stvar samo ustaštva i Hrvatske katoličke crkve, nego i Vatikana, jer se ostvarivao njegov davni san da se bar na jednom delu Balkana, na zapadnom, likvidira ortodoksna crkva i proširi katoličanstvo, bar do Drine. Umesto kritike i prigovora, najviši predstavnik Vatikana izjavljuje da su vesti koje od ustaša prima - „lijepe izjave”... U Rušinovićevoj korespondenciji postoji još jedan dokument, koji baca jako svetlo na stav Vatikana prema masovnom prekrštavanju Srba, popraćenom najkrvavijim terorom. To je pismo od 8. februara 1942. Lorkoviću. On tu kaže: „U subotu sam posjetio Monsinjora Sigismandia (Pietro Sigismondi) koji je šef ureda za Hrvatsku u Vatikanu. On je bio neobično fin i srdačan. Zanima se za prilike u Hrvatskoj i veli mi da je neprijateljska promičba protiv nas dosta aktivna. Došli smo u razgovoru na pitanje prelaznika u Hrvatskoj. Tome se Sveta Stolica veseli, ali opet mi reče, da nas pri tom napada američko i englesko novinarstvo, jer da su svi ti prelazi vršeni pod velikim pritiskom sa strane vlasti, u što Sv. Stolica ne vjeruje, ali je preporučiti da se to provodi postepeno, da bi se izbjegli prigovori, a neugodnosti za Svetu Stolicu. Spomenu mi, da koji put

\footnotetext{
${ }^{7}$ TAJNI DOKUMENTI o odnosima Vatikana i ustaške NDH, Biblioteka novinara Hrvatske, Štamparski zavod „Ognjen Prica”, Zagreb, 1952, str. 101.

${ }^{8}$ Isto, str. 101.
} 
Iskustva i pouke iz prošlosti

i talijansko novinstvo donese vijesti o masovnim prelazima ortodoksa na katolicizam. Ja sam mu obrazlagao stvar kako treba i dokazivao mu kako su svi ti prelaznici bili već jednom katolici, ali pod najgorom silom morali su ostaviti svoju vjeru i apostatirati. Rekao sam mu, da ću izraditi u formi jedne promemorie historijski prikaz o tome sa dokumentima, što je vrlo rado primio i preporučio da to predam kardinalu Maglione-u kad se s njime sastanem." Ovaj dokument je vrlo važan, jer se odnosi na šefa vatikanskog ureda za Hrvatsku, koji je predstavljao najkompetentnije mesto za sva pitanja koja su se odnosila na NDH Sigismondi je, kao i Maglione, izrazio „veselje” nad masovnim prekrštavanjima Srba. On je, bez kolebanja, izjavio da se „tome Sveta Stolica veseli”. Mada je bio informisan o pravom karakteru tog masovnog prekrštavanja i nasilju, ne samo zato jer je pratio američke i engleske napade u štampi, pa i u samoj italijanskoj štampi čitao o tome, smatrao je, kao da je i sam ustaša, da je to „neprijateljska promičba”... On ne kritikuje ustaške metode, već savetuje da se „neprijatelji” na izazivaju previše i da se ta stvar „provodi postepeno”. Što se tiče nasilja nad „prelaznicima” Sigismondi izjavljuje da "Sveta Stolica ne vjeruje” u to! Ali, sa zadovoljstvom sluša kad mu ustaški opunomoćenik tumači stvari „kako treba”(!), te sugeriše da se to razradi u jednom spisku, koji treba predati kardinalu Maglioneu. Baš ustašku tezu treba, dakle, formulisati kako bi stav "Svete Stolice” u pitanju masovnog prekrštavanja Srba bio još opravdavaniji i čvršći! Uostalom, i sam kardinal Maglione je u razgovoru s Rušinovićem 26. februara 1942. rekao da se „Sveta Stolica” veseli masovnom prekrštavanju: „Na koncu mi veli... a što se tiče povratnika, Sveta Stolica se tome veseli, Hrvatska pak može to politički (!) iskoristiti ali treba izbjegavati ono, što neprijateljima daje povoda za pobjedu."9 Nadbiskup Stepinac bio je, logično, direktni eksponent Vatikana u toj velikoj akciji prekrštavanja. On je u Vatikanu, u ime ustaštva, plasirao tezu koja je ustašama konvenirala, a i samoga papu je obrađivao u momentima kad je kod njega moglo biti makar i malog neslaganja ili kolebanja.

\section{Saradnja ustaških vlasti i Katoličke crkve u sprovođenju nasilnog prelaska Srba u katoličku veru}

U „Katoličkom listu” od 15. maja 1941. (pod brojem 4104) objavljene su odredbe Nadbiskupskog duhovnog stola u Zagrebu, sadržane u 7 tačaka, koje objašnjavaju ko se sve sme primiti u katoličku veru, a ko ne. Može se zaključiti da je najviša crkvena vlast u takozvanoj NDH podržala ustašku nameru da se nasilnim aktivnostima likvidira pravoslavlje u Hrvatskoj, te da se oni Srbi, koji nisu pobijeni ili isterani iz zemlje, u što kraćem vremenu prekrste u katolike i automatski pretvore u Hrvate. ${ }^{10}$

lako se u nekim tačkama tih odredaba Duhovnog stola govori o formalnostima koje polaznici moraju ispuniti, pa se naglašava čak i pitanje njihovog "iskrenog” traženja da im se omogući pristup u katoličku veru, te njihovo „uvjerenje”, ipak se po svemu vidi da je najviša crkvena instanca u Hrvatskoj vrlo ozbiljno pristupila ustaškoj akciji i čitav svoj aparat stavila u službu masovnog prekrštavanja. Kako je najviša katolička instanca u Hrvatskoj shvatila prekrštavanje i s kakvom mu je tendencijom pristupila najbolje se vidi iz članaka objavljenih u „Katoličkom listu”, organu zagrebačke nadbiskupije, gde se harangerski pisalo o Srbima i

\footnotetext{
${ }^{9}$ Isto; Pismo Rušinovića Lorkoviću od 26.Il.1942. godine.

${ }^{10}$ „Katolički list” od 15. svibnja 1941. godine.
} 
pravoslavlju. Nije potrebno naglašavati da su te odredbe i komentari službenih crkvenih faktora bili u suprotnosti s postojećim kanonskim propisima o prelaženju na katolicizam. Retko je kada u istoriji, pa ni u doba strašnih verskih ratova, nasilje nad slobodom savesti bilo tako brutalno. Postoje dva akta Pavelićevih „ministarstava”, koja mogu poslužiti kao dokaz o nasilnom prekrštavanju. Dana 30. juna 1941. ustaška vlada izdala je akt, pod brojem $48468 / 41$, o prelazima iz pravoslavne vere, iz kojeg se vidi da se treba rukovoditi „državnom politikom", što znači nikako kanonima, koji ne bi bili povoljni za brzo masovno prekrštavanje. Prelaznici su morali doneti službene potvrde „o ličnoj čestitosti”. Ta se potvrda izdavala „u sporazumu s ustaškim logorima i taborima”, o čemu je trebalo obavestiti i Ministarstvo pravosuđa i bogoštovlja. U tom se aktu kaže da se ne izdaju potvrde, nego samo iznimno, pravoslavnim „popovima, trgovcima, bogatim obrtnicima i seljacima, te uopšte inteligenciji"... Po tome se vidi da su ciljevi bili čisto političko-teroristički, da se pravila razlika, da se unapred određivalo koji će se ljudi primiti u katoličku veru, a koji likvidirati ili iseliti. Najčešće su likvidirani ili iseljavani bogatiji ljudi kako bi im se oduzimala imanja, ali i inteligencija. ${ }^{11}$ Drugi akt je onaj koji je Ministarstvo pravosuđa uputilo 14. jula 1941. (br. 42687-B. 1941) biskupskim ordinarijatima NDH i glasi: „Molimo Preuzvišeni Ordinarijat, da bi u povjerljivoj formi obavijestio sve župske urede u pogledu primanja pravoslavnih u katoličku Crkvu. Pravoslavnima se neće ni u kojem slučaju dopustiti prelaz u grko-katoličku crkvu. Intencije su Hrvatske Vlade, da se u katoličku Crkvu ne primaju pravoslavni popovi, učitelji, zatim uopće inteligencija i napokon bogati sloj trgovaca, obrtnika i seljaka radi kasnijih eventualnih odredaba s obzirom na njih, da se ne bi izvrgavala neugodnostima vjera i ugled katolicizma... Niže i siromašno pravoslavno pučanstvo dopušteno je primiti uz prethodnu pouku u katoličkim istinama. Ukoliko bi i gore spomenuti navaljivali da budu primljeni, treba ih u zgodnoj formi zadržavati u katekumenatu ili na drugi način otkloniti." ${ }^{\text {12 }}$

Državno ravnateljstvo za ponovu imalo je posebni verski odsek. U njegovu nadležnost spadali su poslovi, koji se odnose na „sva pitanja prelaženja iz grčko-istočne (to je ustaški naziv za Srpsku pravoslavnu veru) na katoličku, muslimansku i evangeličku"... Taj odsek izrađivao je planove, kojima je vlada, preko svojih ministarstava, davala zakonsku formu. Do novembra 1941. odsek je, pod vođstvom Dionizija Juričeva, sveštenika, ustaškog satnika i Pavelićevog kapelana, bio jedini vrhovni rukovodilac na poslu katoličenja i u „uskoj vezi s duhovnom vlašću”. Ta ustanova šalje na teren svoje „misionare”, koji su agitovali za prelaz na katoličku veru. Bili su to sveštenici koji su, navodno, imali zadatak da (pod pretnjom i terorom, podržani ustaškim bandama) pripreme što veći broj Srba za prekrštavanje. Sveštenici misionari bili su podređeni tom uredu iz čijeg se dopisa jasno uočavaju metode rada. Opštinskom rukovodstvu u selu Stazi kod Kostajnice Vjerski odsjek Ravnateljstva za ponovu saopštava: „Stoga Vas se upozorava, da sav rad oko pouke i prijelaza svrše (dva misionara) do slijedeće nedjelje, tako da u slijedeću nedjelju bude već čitava općina katolička, da se sve završi prije velike svečanosti od 11.H.1941." Iz pisma Opštinskom povereništvu u Crkvenom Boku od 22. oktobra 1941. vidi se da taj odsek naređuje da se pravoslavna crkva „odmah prema planu općine počne preuređivati za rimokatoličku."13

\footnotetext{
${ }^{11}$ Akt ustaške vlade br. 28468/41, od 30. 6. 1941.

${ }^{12}$ Akt ministarstva pravosuđa ustaške vlade br. 42687-B/1941, od 14, 7. 1941.

${ }^{13}$ TAJNI DOKUMENTI o odnosima Vatikana i ustaške NDH., Biblioteka novinara Hrvatske, Štamparski zavod „Ognjen Prica”, Zagreb, 1952, str. 92-93.
} 
Papa i ostala vatikanska kurija vrlo dobro su znali šta se događa u takozvanoj NDH, a bio im je poznat i postupak sa Srbima pravoslavcima, te velika akcija prekrštavanja. Ustaštvo je imalo podršku iz Vatikana , a i Hrvatska katolička crkva je za svoju saradnju sa ustaškom vladom imala odobrenje. Dana 17. jula 1941. (Prot. N. 2116) vatikanska Sveta kongregacija za Istočnu crkvu izdala je zagrebačkom predsedniku biskupskih konferencija dr Stepincu uputstvo u vezi s prelaženjem pravoslavaca na katoličanstvo. Ono glasi: „Sveta Kongregacija za Istočnu Crkvu svraća pozornost Vašoj Preuzvišenosti da rimokatolički župnici u Hrvatskoj budu potaknuti od svojih preuzvišenih biskupa (nadpastira), da u slučaju prijelaza nesjedinjenih (otpadnika) ne spriječe njihovo prirodno vraćanje u istočni obred kad se radi o onima, koji su prije bili članovi katoličke Crkve (zajednica) istočnog obreda, ali su pod prijetnjama i pritiskom pravoslavnih (ortodoksnih) odstupili od katoličke vjere. Ako Vaša Preuzvišenost predoči tu potrebu svojoj časnoj braći (biskupima) u Hrvatskoj, steći će ponovnu zaslugu tim svojim dragocjenim doprinosom za pravilan razvoj katolicizma, gdje postoje tolike nade za obraćenje nesjedinjenih. Koristeći se rado ovom prilikom ponavljam osjećaje svog poštovanja i bilježim se Vašoj Preuzvišenosti odani kardinal Eugenije Tiserant (Eugène Tisserant)."

U rezoluciji koja je doneta na biskupskoj konferenciji u Zagrebu, 17. novembra 1941, upućenoj Paveliću, citira se spomenuti akt Svete Kongregacije doslovno, s napomenom da „hrvatska katolička crkva u celosti usvaja odredbu Svete Kongrgacije za Istočnu Crkvu od 17.VII.1941.” Nakon što je citirana, u rezoluciji se kaže: „Isto tako u cijelosti prihvaća hrvatski katolički episkopat odredbu Svete Apostolske Stolice od 18. listopada 1941. koja glasi: 'Gde god već postoje organizirane grko-katoličke župe (župe grko-katoličkog odreda), neka se upute ne sjedinjeni, koji se žele obratiti, na iste župe. Ipak u pretpostavci, ako isti odijeljeni ne sjedinjeni neće ili ne mogu održati svoj istočni obred, neka im se dade sloboda prihvatiti latinski obred'". U citiranoj rezoluciji hrvatski episkopat tvrdi da prihvata „te dvije odredbe... to više, što se one u glavnim crtama podudaraju s odredbom okružnice vlade NDH od 30. srpnja broj 46448-41..." Dakle, Sveta Stolica je posebnom, drugom odredbom, koja je tu spomenuta, proširila raniju odredbu Svete kongregacije za Istočnu crkvu, da ne bi ustaška vlada imala poteškoća, jer toliko grkokatoličkih crkava, koje bi mogle preuzeti stotine hiljada pravoslavaca, nije bilo, pa je blagonaklono dozvoljeno da se pravoslavci direktno prebacuju u katolički obred.

\section{Uloga Vatikana u prekrštavanju Srba u NDH}

Kroz klasifikaciju pravoslavaca, koji prelaze na katolicizam jasno se uočavaju metode saradnje Vatikana i NDH na tom planu. To su za Vatikan „odijeljeni ne sjedinjeni”, što je sasvim u duhu ustaške teze. Da bi se bolje osvetlila uloga Hrvatske katoličke crkve, važno je citirati delove rezolucije, kojom se ona obraća Paveliću, tražeći isključivo za sebe kompetenciju po pitanjima prekrštavanja Srba. Biskupi ne žele više biti podređeni u toj akciji Državnom ravnateljstvu za ponovu., pa se obraćaju Paveliću: „Poglavniče! Hrvatski Katolički Episkopat sakupljen na godišnjim plenarnim Konferencijama od 17. i 18. novembra ov.g. (1941) stvorio je ove zaključke o prelazima grkoistočnjaka (pravoslavnih) na katoličku vjeru:

\footnotetext{
${ }^{14}$ Radoslav Gaćinović, Nasilje nad Srbima u XX veku (uzroci i posledice), knjiga druga, EVRO BOOK, Beograd, 2017, str. 183.
} 
1) Smatra dogmatskim načelom, da rješidba svih pitanja, koja se tiču crkvenog prelaza grko istočnjaka na katoličku vjeru spada isključivo na kompetenciju Katoličke Crkvene Hijerarhije, koja je jedina ovlašćena po božanskom pravu i po kanonskim odredbama izdavati za te crkvene prelaze direktive i propisivati odredbe tako, da je mimo crkvenog autoriteta isključena svaka akcija u tom pogledu.

2) Radi toga nitko osim Katoličke Crkvene Hijerarhije nema prava postavljati 'misionare', koji bi imali provađati konverzacije grkoistočnjaka na katoličku vjeru. Svaki takav 'misionar' mora dobiti misiju i jurisdikciju za svoj duhovni rad od mjesnoga Ordinarija. Prema tomu je protudogmatski i protukanonski, da bez mjesnog Ordinarija-biskupa dobivaju 'misionari' misiju od općinskih povjerenika ili oblastnika, od ustaških dužnostnika, od Vjerskog odsjeka državnog Ravnateljstva za ponovu ili od koje druge svjetovne oblasti.

3) Svaki takav 'misionar' mora biti u svom duhovnom radu ovisan samo od mjesnog Ordinarija ili direktno ili indirektno preko mjesnog župnika.

4) Crkva Katolička može priznati valjanim samo one prelaze, koji su se obavili ili će se obaviti prema tim dogmatskim načelima.

5) Svjetovna oblast ne može 'poništavati' one prelaze, koji su crkveno provedeni ne samo prema crkvenim nego i prema građanskim propisima.

6) Hrvatski Katolički Episkopat izabire radi toga iz svoje sredine odbor trojice, u koji ulaze: Predsjednik Biskupskih konferencija, biskup Senjski Mons. Dr. Viktor Buruć i Apostolski Administrator križevačke biskupije Dr. Janko Šimrak. Taj će odbor rješavati i raspravljati sva pitanja, koja dolaze u obzir gledom na konverzacije grkoistočnjaka na katoličku vjeru. On će raditi u dogovoru s gospodinom Ministrom pravosuđa i bogoštovlja, što se tiče odredaba o prelazima.

7) Kao radni izvršni odbor za pitanje konverzacija grkoistočnjaka na katoličku vjeru izabrao je Hrvatski Katolički Episkopat: dr Augustina Juretića, konzultora Biskupskih Konferencija, dr Janka Kalaja, profesora-katehetu na srednjim školama i nastavnika za glagoljicu na bogoslovnom fakultetu, Nikolu Borića, ravnatelja kancelarije zagrebačke nadbiskupije i dr Krunoslava Draganovića, profesora na bogoslovnom fakultetu, koji će odbor rješavati sve poslove oko pitanja konverzija grkoistočnjaka na katoličku vjeru pod nadzorom Odbora Biskupa za konverzije." ${ }^{15}$

O samom nasilju nad Srbima ova rezolucija govori na ovaj jezuitski način: „Poglavniče! Ovi su zaključci Hrv. Episkopata dirigirani prevelikom ljubavlju i brigom za Hrvatski Narod, za Nezavisnu Državu Hrvatsku i za katoličku vjeru, koja je vjera ogromne većine Hrvatskog Naroda. Na ovom mjestu je govor samo o pogrješkama, radi kojih se konverzije grkoistočnjaka nijesu mogle razvijati u onom obimu i sa onim uspjehom, kako bi se one bile razvijale, kad te pogrješke ne bi bile učinjene". Hrvatska katolička crkva o zločinima govori blago kao o nekim „pogrješkama” neodgovornih, pa čak i to opravdava provokacijom od strane žrtava! Crkveno rukovodstvo ne osuđuje zločine („neodgovornih"), nego samo žali što su te „pogrješke” umanjile uspjehe masovne akcije prekrštavanja. Katolička crkva je, naime, želela da se Srbi lukavije privode, jer bi „obim” i „uspjeh” bio veći. Međutim, stvari se, u suštini, nisu izmenile. ${ }^{16}$ Nasilje nad Srbima nastavljalo se i dalje istom žestinom. Kako su na ponašanje Vatikana gledali neki sveštenički krugovi vidi se iz promemorije, koju su slovenački

\footnotetext{
${ }^{15}$ Isto, str. 184,

${ }^{16}$ TAJNI DOKUMENTI o odnosima Vatikana i ustaške NDH, Biblioteka novinara Hrvatske, Štamparski zavod „Ognjen Prica”, Zagreb, 1952, str. 97; „Katolički list” od 15. svibnja 1941. godine.
} 
katolički sveštenici, koji su se nalazili kao izbeglice u Srbiji, predali 1. marta 1942. beogradskom nadbiskupu dr. Josipu Ujčiću, s tim da je on prosledi Vatikanu. U opširnom tekstu slovenački sveštenici iznose prilike u kojima žive Srbi koji su ostali u NDH, s naročitim osvrtom na prekrštavanje. Oni, takođe, kažu: „Konačni cilj zagrebačke politike je uništenje srpskog naroda u NDH. Tom nemoralnom cilju ima poslužiti i pokatoličavanje... Šta se događa u Hrvatskoj, ne samo da ne proizlazi iz bilo kakvih vjersnih pobuda, već štoviše u suštini predstavlja ponižavajuću zloupotrebu katoličke crkve i sudbonosno gažanje njenoga ugleda i dostojanstva... atmosferi nesmanjenih pretnji, koje se čine danas u Hrvatskoj, dalo bi se na prste jedne ruke nabrojiti one pravoslavce, koji se prijavljuju za prelaz po slobodnoj svojoj volji i iz unutarnjih osvjedočenja u istinitost katoličkog učenja."

\section{Alojzije Stepinac - glavni inspirator u organizovanju pokatoličavanja Srba u NDH}

U izveštaju Nikole Rušinovića Lorkoviću od 9. maja 1942. vidi se da je Stepinac posredovao između Vatikana i ustaštva i kakve je ideje zagovarao u Vatikanu. Rušinović piše da je Stepinac bio 12 dana u Rimu, da je tamo bio dobro raspoložen „a upravo borbeno protiv svih mogućih neprijatelja naše Države.” O radu Stepinca u Rimu Rušinović piše: „On je podnio izvještaj Sv. Ocu, 9. stranica pisanih na stroju. On mi je u glavnom pokazao taj izvještaj, pa Te mogu osigurati, da je s našeg stanovišta apsolutno pozitivan. Napadajući na Srbe-četnike i komuniste, kao začetnike svega zla što se zbilo u Hrvatskoj, našao je materijala, za koji nisam ni ja znao. Neću ti ih nabrajati pojedina zlodjela, koja je on naveo, ali znaj, da je to bio upravo dragoceni prilog svemu onome što sam do sada ja radio." ${ }^{18}$ Položaj u zemlji on ocenjuje povoljno i hvali rad i aktivnost vlade. O poglavnikovim naporima i brizi da se što pre uspostavi red, te o njegovom verskom raspoloženju i postupku prema crkvi govori najlepšim rečima. Kaže da je sigurniji nego ikada pre za sudbinu hrvatskog naroda i države, jer su rukovodstvo i sam narod pokazali volju i smisao da očuvaju ono što su navodno dobili. Ne može se i ne sme dozvoliti, kaže on, da bilo ko napada NDH i da baca loše svetlo na hrvatski narod, pa je zato došao u Rim da pobija navodno laži, koje su servirane Svetoj stolici. Nakon podnetog izveštaja bio je primljen kod Sv. Oca i zadržao se s njim u razgovoru jedan sat, a zatim je posetio Maglionea, te razne kardinale i druge vatikanske dostojanstvenike. Govorio je o raznim pitanjima, posebno o pravoslavnima, te o Talijanima u Dalmaciji i obalnom pojasu, o njihovom postupku prema katoličkoj crkvi, narodu i o njihovom držanju prema šizmaticima. O svim razgovorima izvestio je poglavnika. ${ }^{19}$ Stepinac je, što se iz ovog pisma vidi, prilikom ove posete Rimu radio sasvim u ustaškom duhu. Izveštaj koji je podneo Svetoj stolici, a i samom papi, u toku jednosatne audijencije, sasvim je na ustaškoj liniji, kako svedoči Rušinović, koji je imao uvida u Stepinčev izveštaj od 9 stranica. Sa ustaškog stanovišta sve je bilo „apsolutno pozitivno”. Stepinac je Pavelićevo nasilje prikazao samo kao nastojanje da „čim prije uspostavi red”, a prikazao ga je i kao

\footnotetext{
${ }^{17}$ Radoslav Gaćinović, Nasilje nad Srbima u XX veku (uzroci i posledice), knjiga druga, EVRO BOOK, Beograd, 2017, str. 185.

18 Isto.

${ }^{19}$ TAJNI DOKUMENTI o odnosima Vatikana i ustaške NDH, Biblioteka novinara Hrvatske, Štamparski zavod „Ognjen Prica”, Zagreb, 1952, str. 104.
} 
bogobojaznog čoveka, te kao zaslužnoga za crkvu. Stepinac je smatrao da se ne sme dozvoliti napadanje na NDH - „pa je zato došao u Rim da pobija laži koje su servirane Svetoj Stolici.”! On je razgovarao i sa papom o Srbima u Hrvatskoj. Papa se složio, jer je Stepinac imao nameru da po povratku referiše lično Paveliću o dobrom dojmu koji ustaštvo ostavlja kod Svete stolice i samog pape. Nesumnjivo je da je u Vatikanu vladala velika naklonost prema ustaštvu, što je učvrstilo i Stepinčevo ustaštvo, jer je Stepinac na Rušinovićevu banketu držao zanosne ustaške zdravice, koje ultraustaša Rušinović naziva „vrlo lijepima”. ${ }^{20}$ S lažnim argumentima i istorijskim falsifikatima Alojzije Stepinac je kod pape podržavao ustaško istrebljivanje Srba i pravoslavlja, što znači i likvidiranje i masovno prekrštavanje. To je bila teza koju su priznavali i odobravali i papa i čitava vatikanska kurija. Posebno je interesantno Stepinčevo isticanje da ustaška Hrvatska brani i papinu Italiju od - pravoslavlja! Ne samo iz vatikanskih dekreta i reagovanja, koja dolaze do izražaja u „diplomatskoj” korespondenciji, nego i po svemu ostalom, pa i po ponašanju zagrebačkog nadbiskupa, jasno se vidi da je Vatikanu konveniralo ono što je ustaštvo sprovodilo, jer je cilj bio zajednički: što čvršća granica katoličke crkve na Drini, što je „opravdavalo" sve, pa i more krvi i suza stotina hiljada žrtava.

Organizovano, nasilno prevođenje pravoslavnog stanovništva u katoličanstvo bilo je sastavni deo genocidnog procesa; sprovođeno je kroz spregu klera i ustaša. „Zakonsko” pokriće ove akcije obezbeđivala je ustaška vlast, a moralni vid samog čina nije predstavljalo opterećenje za Vatikan, po kojem grčka vera nije vera (Greca fides nulla fides). Vatikan je ostvario u Hrvatskoj ono što nije uspeo da ostvari u zapadnom svetu - da nacionalno identifikuje sa verom. U toj konstrukciji prekrštavanje se pojavilo kao sastavni deo borbe za „etničku čistotu hrvatske države”. U svom dnevniku Stepinac je, 17. januara 1940, zapisao: „Najidealnije bi bilo da se Srbi vrate vjeri svojih otaca, tj. da prignu glavu pred namjesnikom Hristovim Svetim Ocem (papom). Onda bi i mi konačno mogli odahnuti u ovom djelu Evrope". ${ }^{21}$

Donošenje „zakonskih "propisa o prevođenju u katoličanstvo, što je bilo u nadležnosti poglavnika, bilo je do detalja usklađeno sa akcijom Zagrebačke nadbiskupije. Krajem aprila 1941. ukinute su „sve srpske konfecionalne pučke škole i zabavišta." ${ }^{22}$ Samo nekoliko dana kasnije zabranjeno je ćirilično pismo, na kojem su bile štampane sve crkvene knjige. Upotreba ćirilice smatrana je krivičnim delom. Otpočelo se odmah i sa rušenjem srpskih pravoslavnih crkava, a ponegde su pretvorene u katoličke. Manastir Orahovica u Slavoniji ustupljen je „trapistima”, koje je Hitler proterao iz Rajhenburga (Reichenburg). $\mathrm{Na}$ zahtev nadbiskupa dr Stepinca manastir Lepavina predat je križevačkom biskupu dr Janku Šimraku. Episkopski dvor u Pakracu, sa sabornom crkvom i kulturnoistorijskim spomenicima od neprocenjive vrednosti, dodeljen je franjevačkom redu sv. Ćirila i Metodija u Zagrebu, dok je crkva Sv. Ilije u istom mestu srušena. Slična sudbina zadesila je i ostale pravoslavne sakralne objekte u Hrvatskoj. ${ }^{23} \mathrm{U}$ aktu biskupskog ordinarijata Đakovačke biskupije, br. 848/42, od 14. februara 1942. navedena su precizna uputstva o pretvaranju pravoslavnih crkava u katoličke.

\footnotetext{
${ }^{20}$ Isto, str. 106-107; Viktor Novak, MAGNUM CRIMEN - pola vijeka klerikalizma u Hrvatskoj, Zagreb, MCMXLVIII i Nova knjiga, Beograd, MCMLXXXVI.

${ }^{21}$ Sima Simić, Prekrštavanje Srba za vreme Drugog svetskog rata, Grafički zavod, Titograd, 1958. str. 25.

${ }^{22}$ Narodne novine, 21. travanj, 1941.

${ }^{23}$ Za vreme četvorogodišnje ustaške vladavine srušeno je ili spaljeno blizu 500 pravoslavnih crkava, što je imalo za cilj lišavanje stanovništva duhovnog oslonca (Radoslav Gaćinović, Nasilje nad Srbima u XX veku (uzroci i posledice), knjiga druga, EVRO BOOK, Beograd, 2017, str. 186).
} 
Iskustva i pouke iz prošlosti

Zakonsku odredbu o prelasku s jedne vere na drugu, od 3. maja $1941,{ }^{24}$ sva štampa u NDH pozdravila je kao „povjesni čin”. Ministar bogoštovlja i nastave dr Mile Budak izdao je „Uput” o prelazu s jedne vere na drugu, ${ }^{25}$ kako bi se ubrzao postupak prevođenja. Naredbom ministra pravosuđa dr Mirka Puka naziv „srpsko-pravoslavna vjera” promenjen je u „grčko-istočna vjera". ${ }^{26}$ Zakonska regulativa bila je dopunjavana crkvenim propisima. Nadbiskupska kancelarija svojom Okruženicom br. 4104/41, od 15. maja, polazeći od teze da mnoge osobe „žele prijeći u katoličku crkvu”, utvrdila je uslove prijema „otpadnika”. Pristup u Katoličku crkvu glasi u t.1 Okružnice, „može se dopustiti samo onim osobama, za koje postoji osvjedočenje naše svete vjere, i o njenoj potrebi za spas duše." A zatim se u t.6 upozorava: „dušebrižno svećenstvo, da u ovim delikatnim pitanjima ljudske duše postupa strogo po načelima katoličke crkve, čuvajući njeno dostojanstvo i ugled, te a limine odbija one, koji bi u crkvu htjeli ući bez ispravnih motiva, tražeći u njoj samo zaštitu svojih materijalnih i egoističnih ciljeva." ${ }^{\text {27 }}$ Profesor Teološkog fakulteta u Zagrebu dr Stjepan Bakšić izradio je Propise za prijem u Katoličku crkvu. Prekrštavanje je bilo državno-crkveni program NDH, ali se i tu vršila određena selekcija. U jednom raspisu, Okružnici od 30. jula, koju su zajednički izdali Glavni ustaški stan i tri resorna ministarstva vlade NDH, uz prethodno savetovanje sa Nadbiskupijom, naglašeno je da prelaz Jevreja „na katolicizam ne može imati nikako upliva na položaj tih osoba u njihovom odnosu prema državi, obzirom na postojeći Zakon o nearijevcima". Prekrštavanje je bilo namenjeno samo Srbima, ali ne svima. Načelan stav vlade bio je da se u katoličanstvo prevedu siromašni slojevi. Računalo se s niskim obrazovnim stepenom ovih slojeva, pa se pretpostavljalo da bi oni bili spremni da za sitne ustupke bezrezervno slede ustašku politiku. „Pravoslavno sveštenstvo našlo se među prvim žrtvama genocida 1941. Samo u prvim mesecima NDH ubijeno je 128 sveštenih lica i 5 episkopa, a do kraja rata taj broj premašio je 300. Mitropolit zagrebački gosp. Dositej Vasić i banjalučki Platon Jovanović bili su podvrgnuti na javnim mestima svirepoj torturi, i umirali su u najtežim mukama. I u drugom genocidnom talasu našli su se na udaru brojni pravoslavni sveštenici. Sprega države i crkve u sprovođenju politike pokrštavanja učvršćena je formiranjem Vjerskog odsjeka, pri Državnom ravnateljstvu za ponovu, na čijem je čelu bio katolički sveštenik Dionisije Juričev, dugogodišnji zakleti ustaša i najbliži saradnik Pavelićev. U nadležnost 'Vjerskog odsjeka', pored pokrštavanja, ulazilo je i raspuštanje pravoslavnih crkvenih opština i likvidacija njihove imovine."

Tokom 1941. godine prekrštavanje srpskog stanovništva na teritoriji NDH vršilo se, uglavnom, putem nasilja i terora, i on nije davao očekivane rezultate. Uznemirenost stanovništva rasla je iz dana u dan. Takvo stanje nije odgovaralo ni vojnim ni civilnim okupacionim snagama, što je uticalo na ustašku vlast da ublaži mere prekrštavanja ili da promeni metod rada. Do toga je došlo tokom 1942. godine. Osim prekrštavanja u katoličku veru, pravoslavno stanovništvo je prelazilo i na islam, mada u manjoj meri. Bio je to bojkot pravoslavnog stanovništva izazvan pretnjama klero-ustaša. Najveći broj pravoslavnih koji su primili islam bilo je u Prijedoru. Ovakav postupak izazvao je veliko negodovanje ustaša, koji su napravili pokolj Srba u selu Begovo Brdo kod Cetingrada. ${ }^{29}$

\footnotetext{
${ }^{24}$ Narodne novine, 5. studeni 1941, dopune.

${ }^{25}$ Narodne novine, 27. svibnja 1941, dopuna.

${ }^{26}$ Narodne novine, 19. srpnja 1941.

${ }^{27}$ Katolički list, br. 19,15. svibnja 1941.

${ }^{28}$ Smilja Avramov, Genocid u Jugoslaviji 1941-1945, 1991..., I tom, Akademija za diplomatiju i bezbednost i IGAM, 1. dopunjeno i prošireno izdanje, Beograd, 2008, str. 370- 371.

${ }^{29}$ Prof. dr Aleksandar Rastović, Sedamdesetogodišnjica bitke na Kozari, Zbornik radova „Kozara spomenik našeg pamćenja”, Organizacioni odbor za obeležavanje sedamdesetogodišnjice bitke na Kozari, Beograd, 2012, str. 29.
} 
Poslanik u NDH u Rimu dr Stjepo Perić izvestio je papskog nuncija 17. septembra 1941. da je prevedeno 350.000 pravoslavaca u katoličanstvo. Na sumnjičavo pitanje i primedbu nuncija da je za prelaz potrebno „osjećanje”,Perić je odgovorio: „Osjećanje će doći naknadno." ${ }^{30}$ Prelaznici su bili podvrgnuti duhovnoj torturi i strogoj kontroli. Mesni sveštenici izdavali su im svake nedelje pismene potvrde sa datumom „da su obavili vjerske dužnosti." ${ }^{11}$

\section{Protest Svetog arhijerejskog sinoda Srpske pravoslavne crkve}

Sveti arhijerejski sinod Srpske pravoslavne crkve uputio je protest nemačkim okupacionim snagama u Srbiji, a zatim, 15. januara 1942, nemačkom generalu Ludvigu fon Šrederu (Ludwig fon Schröder), ukazujući da se „terorom prevode u katolicizam” mnogobrojni Srbi. Katolički sveštenici „dolaze sa naoružanim ustašama, zatvaraju pravoslavne crkve i oduzimaju crkvene matice, pošto prethodno opljačkaju sve crkvene dragocenosti”. Nadbiskup beogradski dr Ujčić uputio je pismo papi Piju XII, 24. jula 1942, postavljajući pitanje: „Pojedini pravoslavci, da bi izbegli neprijatnosti, prelaze u katoličanstvo... Ali čemu to služi, kada nedostaje religiozno ubeđenje”. 32 Odgovorio mu je kardinal Luiđi Maljone 1. maja 1942. na uobičajeno jezuitski način: „U pitanju su disidenti koji se vraćaju katoličkoj crkvi u Hrvatskoj... To je plod intimnog uverenja, a ne prinude bilo sa koje strane". Kakve planove ima Zagreb sa ovim preobraćanjem pravoslavnih rekao je upravo sa savršenom iskrenošću jedan od najuticajnijih ljudi u Hrvatskoj, ministar mr Mile Budak. On je u Gospiću službeno izjavio: „Jedan dio Srba ćemo pobiti, drugi raseliti, a ostale ćemo prevesti u katoličku vjeru i tako pretopiti u Hrvate". ${ }^{33}$ Po uzoru na nacističku Nemačku ustaše primoravaju Srbe da pređu u katoličanstvo. Tako su, 2. decembra 1941. godine, u Brčkom streljali pedeset Srba, a ostali su morali potpisati formulare o prelasku na katolicizam. Tokom 1941. i 1942. godine na teritoriji NDH pokatoličeno je više od 240.000 Srba. $^{34}$

Da je prekrštavanje vršeno pod najvećim nasiljem i da je vrh katoličke crkve koristio nasilje da poveća broj vernika (isključujući Srbe koje su ustaše naročito obeležile), vidi se po okružnici koja je štampana u Biskupskoj štampariji u Đakovu, koja poziva Srbe da se „čim prije prijave u katoličku crkvu”, jer će kao katolici moći ostati u svojim domovima i nesmetano se posvetiti svojim poslovima i odgoju dece. Srbi su sa strahom čitali te pozive, koji su im jasno govorili šta ih čeka ukoliko ne pređu na katoličku veru. A kako je to „dobrovolino prekrštavanje” izgledalo vidi se iz izjava onih koji su to lično doživeli ili po"smatrali. ${ }^{35}$ Za katoličku Italiju prekrštavanje je bilo duboko antihrišćanski potez. Pavelić je to odmah shvatio, pa je u daljim kontaktima sa predstavnicima Italije pokatoličavanje predstavio kao politički program. Italijanski general Pjetromarki (Pietromarchi), u opšir-

\footnotetext{
${ }^{30}$ ADSS, Vol.5. pp. 244-245.

${ }^{31}$ Katolicki tjednik, br. 31,3. kolovoza 1941.

${ }^{32}$ ADSS, Vol. 5, pp.104-105, A.E.S.6039/41.

${ }^{33}$ Smilja Avramov, Genocid u Jugoslaviji 1941-1945, 1991..., I tom, Akademija za diplomatiju i bezbednost i IGAM, 1. dopunjeno i prošireno izdanje, Beograd, 2008, str. 372.

${ }^{34}$ Radoslav Gaćinović, Nasilje nad Srbima u XX veku (uzroci i posledice), knjiga druga, EVRO BOOK, Beograd, 2017, str. 186.

${ }^{35}$ Antun Miletić, Ustaška fabrika smrti 1941-1945, Vojnoizdavački i novinski centar, Beograd, 1988, str. 21-22.
} 
nom izveštaju grofu Đanu (Galeazzo Ciano) o stanju u NDH prenosi svoj razgovor sa Pavelićem i odlučnost poglavnika da reši srpski problem krajnje radikalnim metodama, sada je, navodi se dalje u izvešaju, Pavelić „usmerio sve svoje nade na proces prevođenja pravoslavaca u katoličanstvo." Politika prevođenja „predstavlja osnovu njegovog programa”. On pri tome polazi od postavke „da srpsko-pravoslavna crkva nije verski, nego politički organizam", a pri tome ističe da su pravoslavci u Hrvatskoj po poreklu i jeziku Hrvati. Uništavanjem pravoslavne crkve, prenosi Pjetro Marki reči poglavnikove, „Srbija će biti definitivno eliminisana iz regiona koji gravitira ka Jadranu i biće prinuđena da zauvek poklekne i sahrani nade." Poglavnik je zatim uveravao svog gosta da prelazak u katoličanstvo nema "gigantske proporcije: već je 250.000 pravoslavaca prešlo u katoličanstvo." Svoj izveštaj završava rečima: „Na svaki način treba isključiti da je taj pokret spontan”. Motivaciju i objašnjenje za prelaz u katoličanstvo on nalazi u negiranju građanskih i političkih prava pravoslavaca. ${ }^{36}$

U Drugom svetskom ratu, u Nezavisnoj Državi Hrvatskoj, najokrutnije je demantovana stara latinska sentenca: Ars longa, vita brevis (Umetnost je duga, život kratak). ${ }^{37}$

\section{Literatura}

[1] Avramov, S. Genocid u Jugoslaviji 1941-1945, 1991..., I tom, Akademija za diplomatiju i bezbednost i IGAM, 1. dopunjeno i prošireno izdanje, Beograd, 2008.

[2] Bulajić,. M. Ustaški zločini genocida i suđenje Andriji Artukoviću, I - II, Beograd, 1988.

[3] Gaćinović,. R. „Savremeni terorizam” „Grafomark” Beograd 1998.

[4] Davidov,. D. „Totalni genocid - Nezavisna država Hrvatska 1941-1945”, Zavod za udžbenike, Beograd, 2013.

[5] Ekmečić,. M. Dugo kretanje između klanja i oranja - istorija Srba u novom veku (1492-1992), Četvrto izdanje, EVRO GIUNTI, Beograd, 2011.

[6] Miletić,. A. Ustaška fabrika smrti 1941-1945, Vojnoizdavački i novinski centar, Beograd, 1988.

[7] Novak, V. MAGNUM CRIMEN - pola vijeka klerikalizma u Hrvatskoj, Zagreb, MCMXLVIII i Nova knjiga, Beograd, MCMLXXXVI.

[8] Rastović, A. Sedamdesetogodišnjica bitke na Kozari, Zbornik radova „Kozara spomenik našeg pamćenja", Organizacioni odbor za obeležavanje sedamdesetogodišnjice bitke na Kozari, Beograd, 2012.

[9] Simić, S, Prekrštavanje Srba za vreme Drugog svetskog rata, Grafički zavod, Titograd, 1958.

\footnotetext{
${ }^{36}$ DDI, Vol.pp.715-717, II capo dell'ufficio armistizio pace, Pietromarchi al Ministro degli Esteri Ciano, Roma, 30 ottobre 1941.

${ }^{37}$ Život oko milion pravoslavnih Srba, ne samo da je bio prekraćen, već su uništeni njihovi istorijski koreni, crkveno-umetnički spomenici. Sudbina srpskih crkava, ističe neraskidivo je vezana za tragičnu sudbinu srpskog naroda u Hrvatskoj nad kojim je izvršen genocid. Davnašnja humanistička opomena Hajnriha Hajnea (Christian Johann Heinrich Heine): "Kad počnu da spaljuju knjige, odmah iza toga počeće da spaljuje ljude", što se odnosilo na nacističku Nemačku, u ustaškoj Hrvatskoj se tragičnije obistinila. $U$ toj državi, u isto vreme i na istom mestu, spaljivani su i ljudi i knjige. Crkve su postale lomače, ponegde i klanice. Hramovi hrišćanskog, pravoslavnog bogosluženja pretvoreni su u stratišta samo zbog toga što su pripadali pravoslavnom obredu. Ustaški naredbodavci, izvršioci i učesnici genocida nad srpskim narodom, među kojima su bili i sveštenoslužitelji rimokatoličke crkve, znali su dobro da je svaka uništena crkva pokušaj, ali i cilj da se razori srpsko nacionalno biće u Hrvatskoj, da se satre i zatre njegovo istorijsko prisustvo, njegovi koreni i crkveno-umetničke vrednosti. Ne treba nikada zaboraviti da je na teritoriji NDH ostvaren biološki, kulturni i duhovni genocid. Bio je to totalni genocid(Akademik Dinko Davidov "Totalni genocid - Nezavisna država Hrvatska 1941-1945", Zavod za udžbenike, Beograd, 2013. godine).
} 